\title{
Laryngology
}

\section{and Otology}
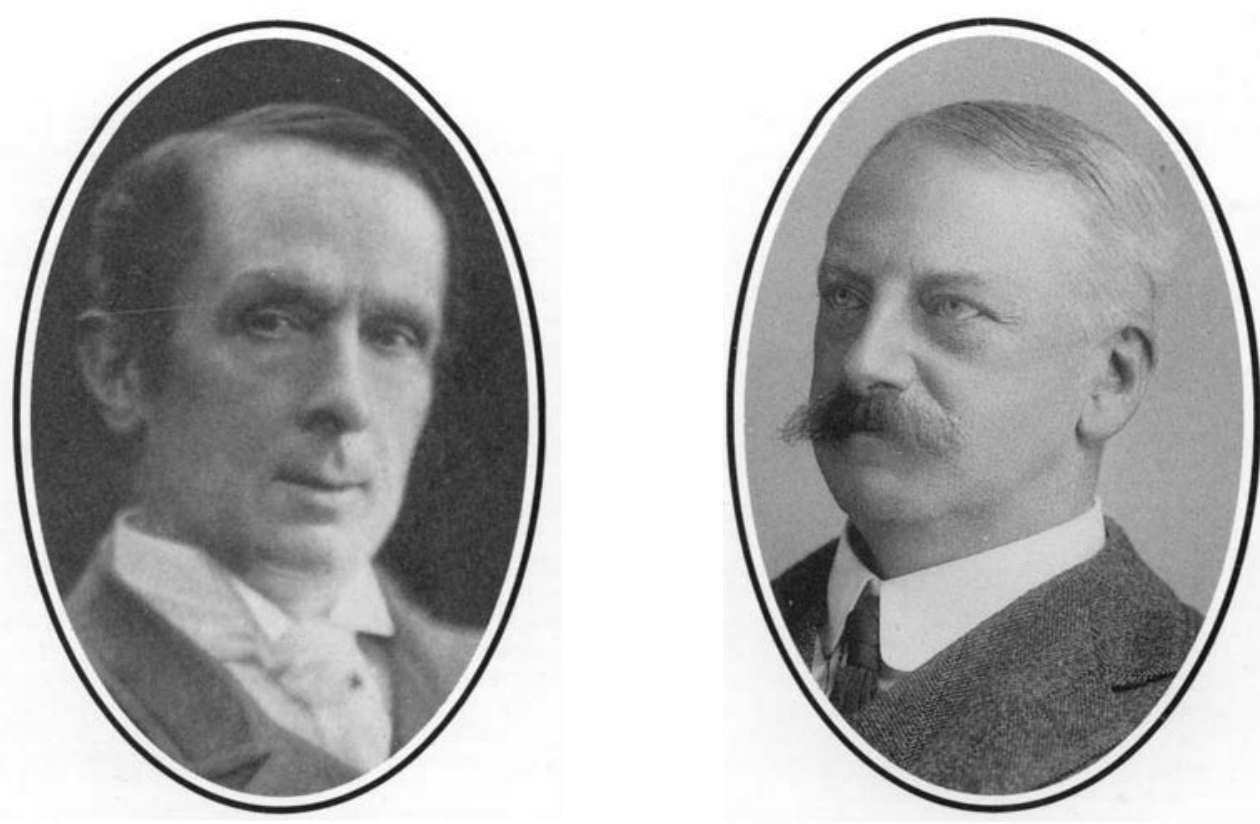

Founded in 1887 by Morell Mackenzie \& Norris Wolfenden

Edited by JOHN B. BOOTH

Assistant Editors NEIL WEIR, PATRICK BEASLEY, CAROL WENGRAF, RICHARD RAMSDEN, IOLO GRIFFITH \& PETER RHŶS EVANS

Advisor in Pathology IMRICH FRIEDMANN

Advisor in Audiology LINDA LUXON

Advisors in Radiology GLYN LLOYD \& PETER PHELPS

Advisors in Statistics ANTHONY HUGHES, PETER KELLY \& GILLIAN RAAB 


\title{
The Journal of Laryngology and Otology
}

\author{
(Founded in 1887 by MORELL MACKENZIE and NORRIS WOLFENDEN)
} Edited by JOHN B. BOOTH

\section{Assistant Editors NEIL WEIR, PATRICK BEASLEY, CAROL WENGRAF, RICHARD RAMSDEN, IOLO GRIFFITH \& PETER RHŶS EVANS INSTRUCTIONS FOR AUTHORS}

1. Original articles which have not been published elsewhere are invited and should be sent to the Editor. They are considered for publication on the understanding that they are contributed to this Journa/ solely. Reproduction elsewhere, in whole or in part, is not permitted without the previous written consent of the Author and Editor and the customary acknowledgement must be made. Normally an original main article should not exceed 7500 words.

Longer articles or theses will be considered for publication as Supplements, at the expense of the authors or their employing authorities.

2. Manuscripts should be typewritten in duplicate on one side of the paper only (A4 $297 \times 210 \mathrm{~mm}$ ) and double spaced, with wide margins. Computer print-outs are not favoured.

Begin each component on a new page in the following sequence: title page, abstract, text, acknowledgements, references tables and legends.

(a) Abstract - This should contain not more than 150 words and include a statement of the problem, the method of study results and conclusions; a 'summary' section should not be included in the main manuscript.

(b) Key Words-only those appearing as Medical Subject Headings ( $\mathrm{MeSH}$ ) in the supplement to the Index Medicus may be

used; where no appropriate word(s) are listed those dictated by common sense/usage should be supplied.

(c) Text-Suggested outline-(1) introduction, (2) materials and methods, (3) results, (4) discussion, (5) conclusion.

(d) Tables are adjuncts to the text and should not repeat material already presented.

(e) Illustrations-Two sets of illustrations, one with each copy of the manuscript, must be submitted and all authors should remember that the single column width is $80 \mathrm{~mm}$. One set of illustrations should, therefore, not exceed this width and they should ensure that the essential features are illustrated within this dimension.

Coloured illustrations will be charged to authors, unless a special grant is authorized by the Editor.

Written permission from the publisher must be provided to the Journa/ in order to republish material with copyright elsewhere and also from the senior author where necessary.

(f) Measurements must be in metric units, with Système Internationale (SI) equivalents given in parentheses.

(g) References-For Journa/articles, The Harvard system of recording references should be used, e.g. Green, C. and Brown, D. (1951). The tonsit problem. Journal of Laryngology and Otology 65: 33-38. A paper written by more than two authors should be abbreviated in the text, e.g. Green et al. (1951), but al/ the authors should be given in the list of references. The titles of all Journals should be given without abbreviation. References should be listed in alphabeticalorder; use of the Vancouve system will not be accepted.

For single-author books, the following style should be used: Green, C. (1951). The tonsil prob/em, 2nd edn., vol. 1, Headley Brothers Ltd., Ashford, Kent, p 33-38.

For papers in multi-author books with one or more editors, the reference should include the title of the chapter and the names of the editors, together with the number of the edition as eg: Brown, D. (1951) Examination of the ear. In Diseases of the Ear, Nose and Throat. 2nd Edition. (White, A., Black, B., eds.), Headley Brothers Ltd, Ashford, Kent, p 33-38.

It is most important that authors should verify personally the accuracy of every reference before submitting a paper for publication. The names of authors cited in the References should be given in alphabetical order.

(h) Meetings-If the manuscript was presented at a meeting, the place where it was held, and the date on which it was read must be included and should appear at the foot of the title page.

(i) Financial disclosures-In the submission letter to the Editor, the authors must list all affiliations with or financial involvement in, organizations or entities with a direct financial interest in the subject matter or material of the research discussed in the manuscript.

(j) Declaration. Each manuscript must be accompanied by a letter of declaration to be signed by each author to confirm that they have seen, read and approve the contribution bearing their name.

(k) Rejections-All manuscripts which are rejected will no longer be returned to the authors. Those submitting papers should, therefore, ensure that they retain at least one copy and the reference numbers, if any, of the illustrations. The only exception to this will be those manuscripts with colour illustrations which will be returned automatically by Surface Mail.

(I) Facsimile (FAX). All authors should send a Facsimile number whenever possible to speed communication; this particu larly applies to those outside the United Kingdom. Manuscripts with no visual illustrations ( $X$-rays/pathology) may be sent by facsimile.

3. Page proofs are sent to authors for corrections, which should be kept to a minimum; they must be clearly marked, and no extra matter added. Proofs should be returned within 5 days.

4. Orders for reprints must be sent when returning page proofs, and for this purpose special forms are supplied.

5. Editorial communications may be addressed to The Editor, Journal of Laryngology and Otology, c/o Headley Brothers Ltd., The Invicta Press, Ashford, Kent TN24 8HH or sent by FAX (071-224 1645).

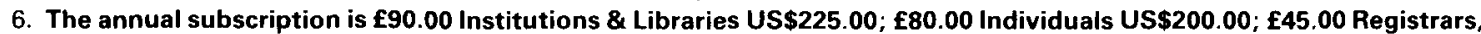
Residents and Interns. (Those in training should submit a certificate from The Head of the Department giving details of their appointment; those who qualify must supply their home address for mailing direct). Claims to be made for missing issues within 6 months of each publication date.

7. Single copies of current or back numbers (when available) will be on sale at $f 12.00$ each (including postage).

8. BINDERS to hold Journals for one year, available at $\mathrm{f} 12.00 \mathrm{each}$

9. SUPPLEMENTS published at 'irregular' intervals with subscription, available separately on request.

10. All subscriptions, advertising and business communications should be sent to the publishers, or subscription agents

\section{HEADLEY BROTHERS LTD,}

THE INVICTA PRESS, ASHFORD, KENT.

(C) Journal of Laryngology and Otology Ltd., 1992

ISSN 0022-2151

Second class postage paid Rahway, N.J.

Postmaster: Send address corrections to The Journal of Laryngology and Otology, c/o Mercury

Airfreight International Ltd. Inc., 2323 Randolph Avenue, Avenel, N.J. 07001 . Frequency of Publication: Monthly. 


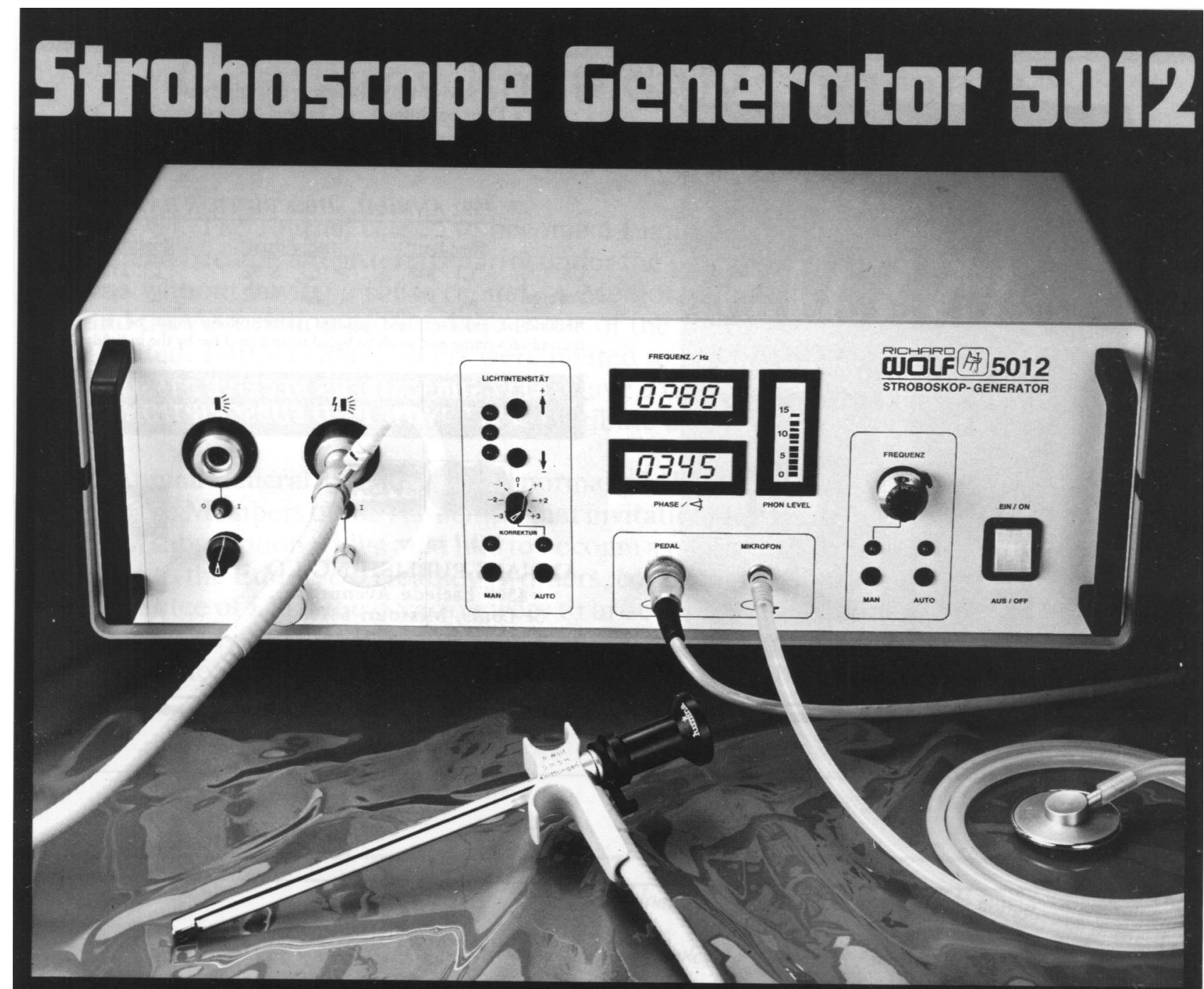

the universal unit for diagnosis of functional disorders of the vocal chords

- simple operation

O high light intensity

- second light connection

- fast and sure triggering even with "poor" phonation

- display of phase, frequency and sound level

- application with rigid or flexible endoscopes

(e. g. magnifying laryngoscope or nasopharyngoscope)

- integrated air insufflator to prevent fogging of magnifying laryngoscope

- can be used in conjunction with video systems and text generators .

Contact us for details:

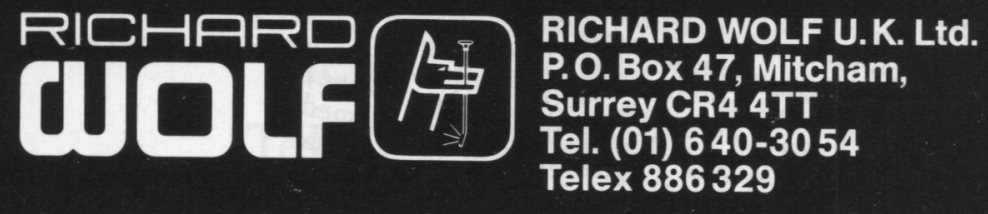




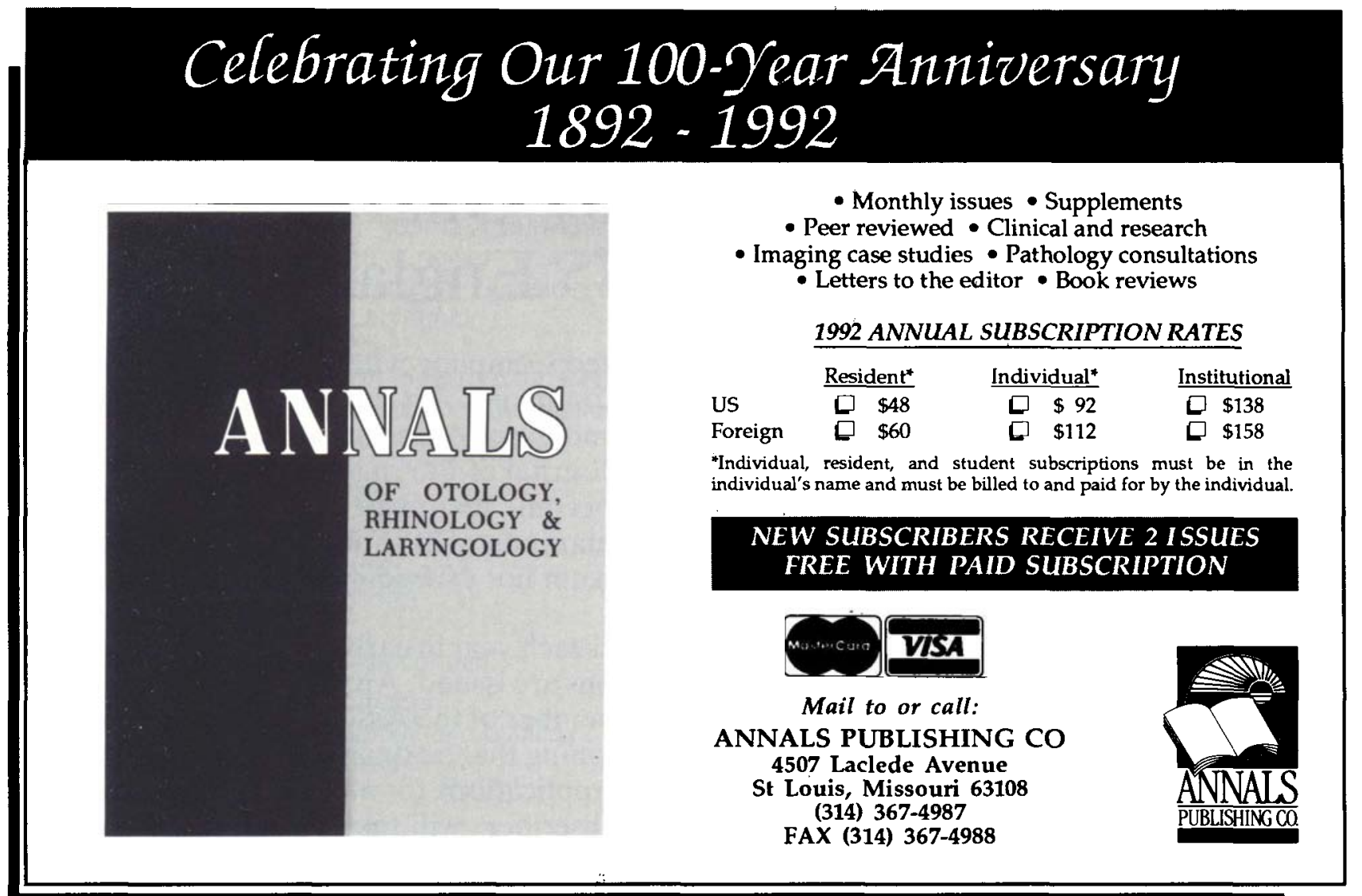

\begin{tabular}{|c|c|}
\hline 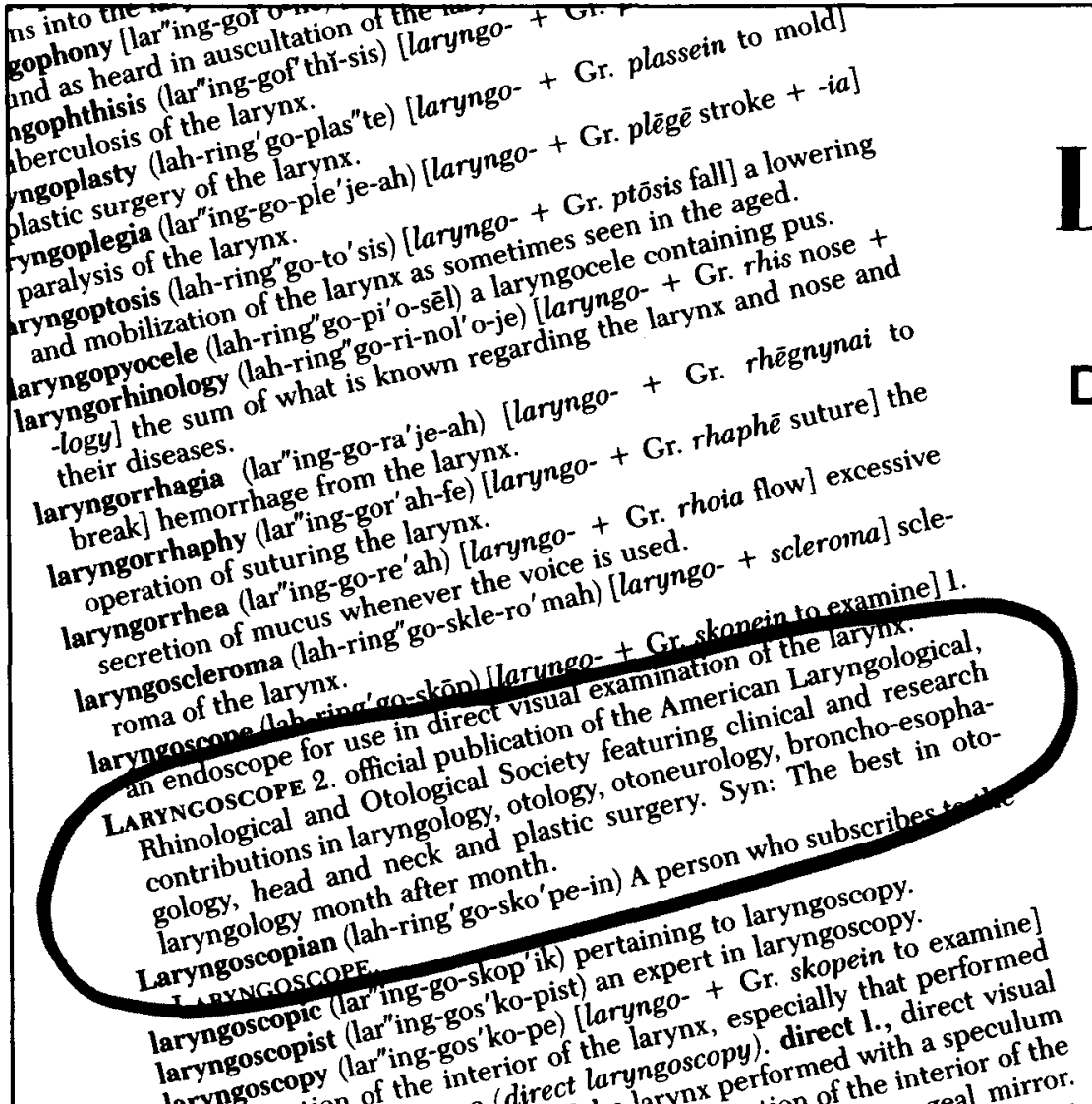 & $\begin{array}{c}\text { fining Otolaryngold } \\
\text { Since } 1896 \\
\text { Inquire: } \\
10 \text { S. Broadway } \\
\text { 14th Floor } \\
\text { St. Louis, MO } 63102\end{array}$ \\
\hline
\end{tabular}




\section{J.L.O. (1984) LIMITED \\ Company limited by Guarantee Reg No: 1865175 England}

In 1984, The Journal ceased to become a Limited Company with shareholders and instead became a registered charity under the Companies Act, limited by guarantee and without having a share capital. A Memorandum of Association was drawn up and the Association acquired the assets of the Journal of Laryngology and Otology Limited. Former shareholders were invited to become members of the Association and all those who undertook to do so, gave a Guarantee that should the association need to be wound up, they would contribute a sum not exceeding $£ 20$.

Annual General Meeting. This is normally held each year in early November, and it is to the Members of the Assocition that invitations are issued. Any individual paying a full subscription who would like to become a member of the Association is asked to write to the Editor, c/o Headley Brothers, confirming that he or she will make such a guarantee of $£ 20$ if the occasion were to arise. Applications for membership may be made at any time. It is hoped that more full subscribers will take up this offer and attend the Annual General Meeting so that there can be a more lively exchange of views between them, and the Editorial staff and publishers.

For Advertisement Rates and Space in this Journal apply to

The Advertisement Manager

THE JOURNAL OF LARYNGOLOGY AND OTOLOGY

\section{Headley Brothers Limited}

The Invicta Press

Ashford

Kent TN24 8HH

Tel: (0233) 623131 


\section{ARE YOU A SUBSCRIBER TO THE J.L.O?}

TEN good reasons why you should:

Each issue, now A4 size, contains 40 per cent more material.

Main Articles, Case Reports and Short Communications from all over the world.

Quarterly Book Review Service.

Selected Abstract Service each month.

Period between acceptance and publication cut to six months or less.

Subscribers receive all supplements produced in that year.

Every 10 years, complete index issue publishedincluded in the subscription (next issue will appear at the end of 1992).

Binder available at cost price to hold each year's issues.

Reduced subscription rates for those in training (Registrars/Residents/Interns).

Subscription normally tax deductible. (Those in training should submit a certificate from the Head of the Department giving details of their appointment; those who qualify must supply their home address for mailing direct.)

The J.L.O. has now been published for more than a century and remains excellent value for money - so why not have your own individual copy and give yourself everyday access! 


\section{Laryngology \& Otology Publications}

\section{Available from the Publishers and from Agents throughout the world. \\ Prices include postage and packing.}

The Journal of Laryngology and Otology

Edited by John B. Booth

A leading international journal, published monthly and containing original scientific articles and clinical records in all fields of Otology, Rhinology and Laryngology. Including occasional supplements.

Founded in 1886

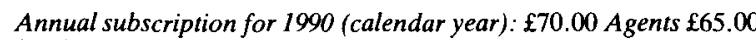
(US\$175.00 Agents $\$ 162.50$ ); Students rate $£ 40.00$

ISSN 00222151

\section{Supplements still available separately.}

\section{Traité de L'Organe de L'Ouïe}

\section{by Nehemiah Asherson}

This Bibliography of one of the earliest accurate descriptions of the organ of hearing, which first appeared in 1683, represents the culmination of a lifetime of historical research. It includes a biographical section on Du Verney, the author of the 'Traité'.

Pp 110 ISBN 0718604474

Retail $£ 7.00$ Agents $£ 6.12$ (US\$14.00 Agents $\$ 12.25$ )

\section{The ENT Surgeon looks at the Orbit}

by D. F. N. Harrison

This supplement records in some detail Professor Harrison's 'personal experience over a period of 20 years dealing with a wide variety of clinical conditions in which entry into the orbit was a desirable or essential part of treatment'

Pp 42 Printed 1980

Retail $£ 4.00$ Agents $£ 3.50$ (US\$8.00 Agents $\$ 7.00$ )

\section{Tinnitus}

Chairman: Abraham Shulman

The Proceedings of The First International Tinnitus Seminar, which was held in New York in June 1979. Practically all the origina papers are reproduced in full, and there are edited versions of all the Panel Discussions. The contributions, from an international group of experts, give comprehensive coverage to a subject of great current interest and importance.

Pp 216 Printed 1981

Retail $£ 10.00$ Agents $£ 8.75$ (US\$20.00 Agents $\$ 17.50$ )

\section{Years Experience with Homografts in Ear Surgery}

by Christian Betow

The author, a professor of Otolaryngology in West Berlin, gives a full account of his pioneering development of homograft materials in reconstructive surgery of the middle ear.

Pp 28 Printed 1982

$$
\text { Retail } £ 4.00 \text { Agents } £ 3.50 \text { (US\$8.00 Agents } \$ 7.00 \text { ) }
$$

\section{Laryngology Applied to Singers and Actors}

by Norman A. Punt

This fascinating monograph fills an obvious void in laryngological literature. The author, eminent in the field of vocal problems in the atre and opera house, writes with understanding, knowledge and concern. When mixed with valuable advice and useful prescriptions, this monograph will serve to guide all who find themselves called upon to help these most sensitive individuals.

Pp 24 Printed 1983

$$
\text { Retail } £ 4.00 \text { Agents } £ 3.50 \text { (US\$8.00 Agents } \$ 7.00 \text { ) }
$$

Experimental and Clinical Studies in Otitis Media with Effusion

by Jamsheed A. Khan

An experimental and clinical study on the effects of Carbocisteine on fluid in the middle ear.

Pp 28 Printed 1983

$$
\text { Retail } £ 4.00 \text { Agents } £ 3.50 \text { (US\$8.00 Agents } \$ 7.00 \text { ) }
$$

Proceedings of the Sixth British Academic Conference in Otolaryngology

Edited by John Ballantyne and John Booth

Pp 134 Printed 1983

Retail $\$ 5.00$ Agents $£ 4.50$ (US\$10.00 Agents $\$ 7.50$ )
Second International Tinnitus Seminar

Chairman: Abraham Shulman

A comprehensive study of the problems and treatment of tinnitus. Pp 323 Printed 1984

Retail $£ 20.00$ Agents $£ 17.50$ (US $\$ 40.00$ Agents $\$ 35.00$ )

Forensic Audiology

by Chuang Wei Ping

A clear concise and practical guide to industrial hearing damage by a barrister/physician. This is an unusual and highly specialised aide memoire for the personal injuries practitioner, well illustrated with recent case law. A commendable enterprise by the author. Pp 57 Printed 1986

Retail $£ 7.00$ Agents $£ 6.12$ (US\$14.00 Agents $\$ 12.25$ )

\section{The Acute Orbit}

Preseptal (Periorbital) cellulitis subperiosteal abscess and orbital cellulitis due to sinusitis.

by J. R. Moloney, N. J. Badham and A. McRae

Pp 18 Printed 1987

Retail $£ 7.00$ Agents $£ 6.12$ (US\$14.00 Agents $\$ 12.25$ )

Nasal Mast Cells: A Preliminary Report on their Ultrastructure

by A. B. Drake-Lee, F.R.C.S

The ultrastructural morphology of mast cells in the nose and the adenoids are compared. Normal cells have a very varied morphology with electron dense granules which have scrolls occasionally. Cells from patients with perennial allergic rhinitis show variable degranulation in all areas examined. Few cells were seen in the surface epithelium. Cells from the adenoids had different degrees of degranulation which suggests that mast cell reactions are not a constant feature.

Pp 17 Printed 1987

Retail $£ 10.00$ Agents $£ 8.75$ (US\$20.00 Agents $\$ 17.50$ )

Surgical Anatomy of Structures Adjacent to the Thyroid Apex and Post-operative Voice Change (A Review Including Dissection)

by K. L. Yerzingatsian, F.R.C.S.

Pp 13 Printed 1987

Retail $£ 10.00$ Agents $£ 8.75$ (US\$20.00 Agents $\$ 17.50$ )

Inferior Meatal Anstrostomy Fundamental Considerations of Design and Function

by Valerie Joan Lund, M.S., F.R.C.S.

Pp 18 (Contains $12 \times 4$ colour illustrations) Printed 1988 Retail $£ 15.00$ Agents $£ 13.12$ (US\$30.00 Agents $\$ 26.25$ )

Surgical Management of the Discharging Mastoid Cavity by R. P. Mills, M.Phil., F.R.C.S.

Pp 6 Printed 1988

Retail $£ 10.00$ Agents $£ 8.75$ (US\$20.00 Agents \$17.50)

Acquired Subglottic Stenosis

by John M. Graham, F.R.C.S.

Pp 48 Printed 1988

Retail $£ 12.00$ Agents $£ 10.50$ (US\$24.00 Agents $\$ 21.00$ )

The University College Hospital/Royal National Institute for the Deaf Cochlear Implant Programme Pp 57 Printed 1989

Retail $£ 15.00$ (US\$30.00) Agents $£ 13.12$ (US\$26.25)

Place-pitch and vowel-pitch comparisons in cochlear implant patients using the Melbourne-Nucleus cochlear implant

by Charles K. Pauka

Pp 31 Printed 1989

Retail $£ 12.00$ (US\$24.00) Agents $£ 10.50$ (US\$21.00) 


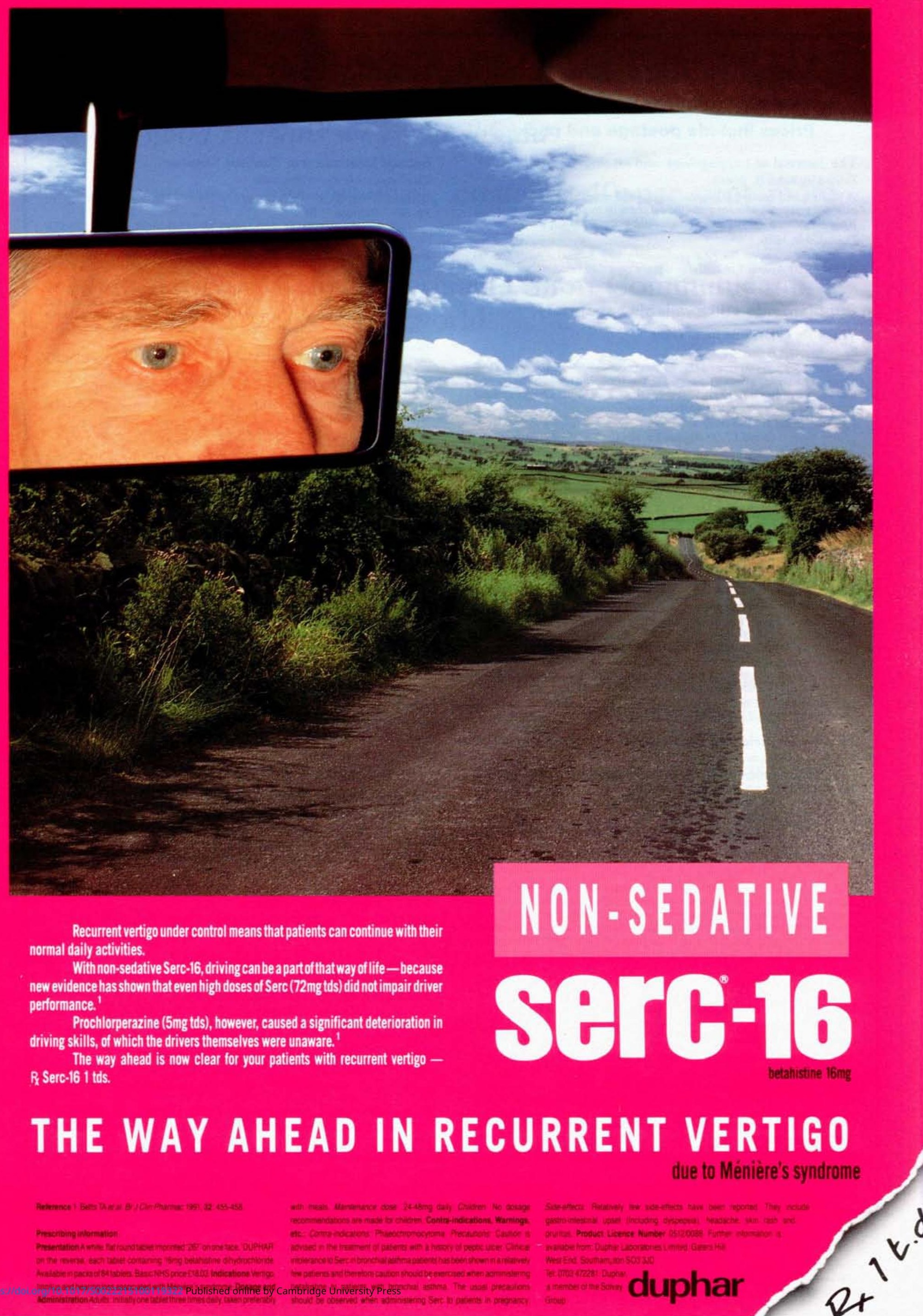

